\title{
Spatial variability of an Alfisol cultivated with sugarcane
}

\author{
Joedna Silva Cruz', Raimundo Nonato de Assis Júnior², Sammy Sidney \\ Rocha Matias ${ }^{3}$, and Jesús Hernán Camacho-Tamayo ${ }^{4}$ \\ 'Departamento de Fitotecnia, Universidade Federal do Ceará - UFC, Av. Mister Hull, s/n - Campus do Pici - \\ CEP 60021-970, Brazil. \\ ${ }^{2}$ Departamento de Ciências do Solo, Universidade Federal do Ceará - UFC, Av. Mister Hull, s/n - Campus \\ do Pici - CEP 60021-970, Brazil. \\ ${ }^{3}$ Universidade Estadual do Piauí - UESPI. Rua Três, 11; Bairro Nova Corrente; CEP 64980-000, Corrente - \\ PI, Brazil. \\ ${ }^{4}$ Programa de Ingeniería Agrícola, Facultad de Ingeniería, Universidad Nacional de Colombia. Ciudad \\ Universitaria, Ed. 214 - Of. 304, Bogotá, Colombia.
}

\begin{abstract}
J. Silva Cruz, R. N. de Assis Júnior, S. S. Rocha Matias, and J.H. Camacho-Tamayo. 2011. Spatial variability of an Alfisol cultivated with sugarcane. Cien. Inv. Agr. 38(1): 155-164. Soil variability occurs due to natural and anthropogenic factors acting at various spatial and temporal scales. The purpose of this study was to evaluate the spatial variability as well as the relation of some chemical attributes using different statistical techniques. The study was conducted in the municipality of Maracanaú (CE, Brazil) in the commercial area of sugar cane in a typic Hapludalf. Soils were sampled in a $100 \times 100 \mathrm{~m}$ grid every $10 \mathrm{~m}$ and at a depth between 0 and $20 \mathrm{~cm}$ for determination of exchangeable acidity, $\mathrm{pH}(\mathrm{KCl}), \mathrm{Ca}, \mathrm{Na}, \mathrm{K}, \mathrm{Mg}, \mathrm{P}, \mathrm{N}$, sum of bases, cationic exchange capacity, base saturation and organic matter. Data were subjected to analysis of descriptive statistics, multivariate analysis and geostatistics. Attributes showed low and medium variability, except for $\mathrm{pH}$ that did not show spatial dependence. Different statistical tools helped to identify the soil spatial variability and to get a better understanding of relationships among different attributes. Techniques also allowed to better plan and control agricultural production, especially in carrying out site specific management of agricultural inputs.
\end{abstract}

Key words: Geostatistics, principal components, cluster analysis.

\section{Introduction}

Natural soil variability occurs due to factors acting on various spatial and temporal scales, caused by complex pedological processes (Burrough, 1993), influenced by relief and humidity regimes (Rezaei and Gilkes, 2005).

Received August 12, 2009. Accepted January 27, 2011. Corresponding author: ymmsa2001@yahoo.com.br
However, crop establishment also modifies soil variability (Burgos et al., 2006), especially by farming work and implementation of agricultural inputs, especially on the surface (Camacho-Tamayo et al., 2008). Mello et al. (2006) found heterogeneous attributes in different soil types and indicated that spatial dependence is conditioned by relief, which causes to determine different management areas from each evaluated attribute of the soil, evidencing the need of carrying out researches in different soil classes. 
In general, there are different tools to identify the behavior of soil attributes, as well as to quantify and characterize them to determine a specific crop; the univariate statistics however, is the most commonly used. According to Fidalski et al. (2007), these statistics may compromise interpretations and conclusions, as the existent dependence among the attributes analyzed is not explored. Other tools, like multivariate statistics and geostatistics, help understand the behavior of soil attributes.

In multivariate statistics, the principal components and hierarchical cluster analysis are widely used in environmental studies for the evaluation, classification and construction of mathematical models for decision making. These are implemented in the study of soil properties to understand attributes variability, and the most important, their dependence between each other, which cannot be verified using univariate statistics (Fidalski et al., 2007). The principal components analysis reduces the dimensions, showing the different basic components, called principal components. Normally, a small number of components explain a high percentage of the total variance, i.e., the data cluster may be described in a smaller dimensional space (Ramos et al., 2007). On the other hand, the hierarchical cluster analysis identifies groups where the attributes present some similarities between each other. The use of these techniques has favored the variability identification of chemical attributes through a cluster of correlated soil attributes (Fidalski et al., 2007; Theodoro et al., 2003).

Geostatistics and especially kriging interpolation are useful tools for map construction and for understanding variability of soil properties in a specific area. This tool may be implemented at different scales in relation to specific data, depending on the resolution desired in the study (Webster, 2008). Characterization of soil spatial variability allows a better representation of the complex relations between the soil characteristics and the environment (Goovaerts, 1998), which helps determine the practices to be used on crops management (Bouma et al., 1999). The search of representative information on spatial soil variability has increased, resulting in more appropriate model developments and management systems for agricultural production (Godwin and Miller, 2003), identifying the relation among soil properties as well as defining homogeneous management areas, as reported by different authors of sugar cane cultivation in order to adopt agriculture precision (Berner et al., 2007; Corá et al., 2004).

The objective of this study was to evaluate the spatial variability of some chemical attributes and their relations, in a Typic Hapludalf cultivated with sugar cane, using univariate statistics, multivariate analysis and geostatistics techniques.

\section{Materials and methods}

The work was carried out in Hacienda Jaçanaú, located in the municipality of Maracanaú (CE, Brazil), with geographical coordenates

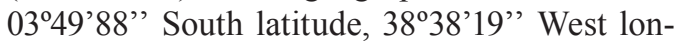
gitude and a mean altitude of $47 \mathrm{~m}$. According to the Köppen classification (1936), the climate in the region is AW', hot and humid, with temperatures higher than $18{ }^{\circ} \mathrm{C}$ in the coldest month, mean precipitation of $1,200 \mathrm{~mm}$, with rains concentrated from February to April. The relief is soft, undulating, with a slope between 2 and $5 \%$. The experiment was made in a sugar cane commercial area, cultivated more than 20 years ago, fertirrigated with manual harvest and without hey burning during the last five years. The soil was classified as Typic Hapludalf of sandy texture, with mean contents of $81 \%$ of sand, $9 \%$ of clay and $10 \%$ of silt.

The samples were collected in points with a regular distance of $10 \mathrm{~m}$, in a grid of $100 \times 100 \mathrm{~m}$, in two perpendicular directions between each other, with a total of 100 points. Samples in the $0.0-0.20 \mathrm{~m}$ layer were collected in each point. The $\mathrm{pH}$, organic matter content, $\mathrm{P}, \mathrm{K}, \mathrm{Ca}, \mathrm{Mg}$, $\mathrm{Na}, \mathrm{H}+\mathrm{Al}$ and $\mathrm{N}$ were determined with these samples, following the methodology proposed by Raij et al. (2001). P and $\mathrm{K}$ were extracted by the resin method. $\mathrm{P}$ was determined by photocolorimeter, $\mathrm{K}$ and $\mathrm{Na}$ by flame emission 
spectrophotometry. $\mathrm{Ca}$ and $\mathrm{Mg}$ were extracted with solution $1 \mathrm{~N}$ of $\mathrm{KCl}$ and were determined by atomic absorption spectrophotometry. $\mathrm{H}+$ $\mathrm{Al}^{3+}$ were extracted with calcium acetate at $\mathrm{pH}$ 7. The sum of bases (SB) was determined from $\mathrm{Ca}, \mathrm{Mg}$ and $\mathrm{K}$, which along $\mathrm{Al}$ define the capacity of cationic exchange (CEC). The saturation by bases (V) was determined based on the relation between SB and CEC.

Initially, a descriptive data study was made for the statistical analysis, calculating mean, median, minimum and maximum, variation coefficient $(\mathrm{CV})$, and also skewness and kurtosis. Therefore, the attribute normality was evaluated, which is not essential, but provides better predictions when it is associated to geostatistical techniques (Diggle and Ribeiro, 2000). The Warrick and Nielsen classification (1980) was used for the $\mathrm{CV}$ analysis, with low variability for values lower than $12 \%$, mean between 12 and $60 \%$, and high for values higher than $60 \%$.

Subsequently, a multivariate analysis was carried out, performing a factor analysis by principal components (AFCP) and hierarchical cluster (AAH), in order to determine the relation among the chemical attributes. The correlation matrix was used for this analysis, where the data from each attribute were previously standardized, with mean 0 and variance 1 . For AFCP, the Varimax rotation was applied. The Euclidian distance was used for AAH, so as to separate an attribute cluster into groups, and the results were represented graphically (dendrogram) in order to facilitate the identification of the groups formed by the attributes analyzed, using the Ward algorithm (Manly, 1997). The analysis of descriptive statistics and multivariate analysis were made with the program SPSS v.17.

The theory of regionalized variables was considered for the experimental semivariograms fit to theoretical models (Vieira, 2000). These models were estimated by the program GS+ v.7 (Robertson, 1998), which adopts the highest value of the determination coefficient $\left(\mathrm{R}^{2}\right)$, the lower residual sum of squares (SQR) and the closest value to one of the correlation coefficient obtained by the method of cross-validation (CV) as criteria for the model selection. The prediction in unsampled zones from each attribute by ordinary kriging was obtained by the resulting models, represented in contour maps, using the program Surfer v.7 (Golden Software Inc., 1999). The correlation among the soil attributes was verified along the maps and the Pearson Linear Correlation Analysis. The classification of the degree of spatial dependence (GDE) was made based on the relation between the nugget effect and sill $(\mathrm{C} / \mathrm{Co}+\mathrm{C})$, assigning strong for GDE higher than $75 \%$, moderate for GDE between 25 and $75 \%$ and low for GDE smaller than 25\% (Cambardella et al., 1994).

\section{Results and discussion}

The results obtained from the descriptive analysis showed that the attributes are close to the normal distribution, as the similar values of the media and the median for each attribute indicated, in addition to the values close to zero of skewness and kurtosis, which was also verified by the Kolmogorov-Smirnov normality test (Table 1). The fit for normality for these attributes, in different soil types, is reported by various authors (Silva et al., 2001; Yemefack et al., 2005; Camacho-Tamayo et al., 2008).

Phosphorous was the only attribute that was not close to normal distribution, with distant media and median values, in addition to presenting a significant normality test. According to Camacho-Tamayo et al. (2008), this behavior with higher values than the natural soil contents and high variability shown by maximum and minimum values, is due to the distribution of this agricultural input through the years, modifying soil contents, especially on the surface, because of the scarce mobility and solubility of this element. According to Cressie (1993), it is convenient to verify that not very long tails are present in the normal distribution, more than in normality, in order to avoid a result compromise, especially when kriging is performed using estimations based on mean values (Warrick and Nielsen, 1980). Another important fact is the occurrence of the proportional effect between the mean and the data variance, across a surface, which allows estimating well defined sill in the semivariograms. 
Table 1. Descriptive statistics of the attributes $\mathrm{pH}, \mathrm{Ca}, \mathrm{Na}, \mathrm{K}, \mathrm{Mg}$, sum of bases (SB), exchangeable acidity $(\mathrm{H}+\mathrm{Al}), \mathrm{P}$, cation exchange capacity (CEC), base saturation (V), organic matter ( OM) and N.

\begin{tabular}{lrrrrrrrr}
\hline Attribute & Mean & Median & CV & Minimum & Maximum & Skewness & Kurtosis & K-S \\
\hline $\mathrm{pH}(\mathrm{KCl})$ & 5.47 & 5.40 & 5.59 & 4.70 & 6.30 & 0.17 & 0.13 & ns \\
$\mathrm{Ca}, \mathrm{cmol}_{\mathrm{c}} \mathrm{dm}^{-3}$ & 1.11 & 1.00 & 32.64 & 0.30 & 2.00 & 0.14 & -0.16 & ns \\
$\mathrm{Na}, \mathrm{cmol}_{\mathrm{c}} \mathrm{dm}^{-3}$ & 0.96 & 1.00 & 9.87 & 0.80 & 1.10 & 0.02 & -0.9 & ns \\
$\mathrm{K}, \mathrm{cmol}_{\mathrm{c}} \mathrm{dm}^{-3}$ & 2.60 & 2.60 & 23.47 & 1.20 & 3.90 & 0.23 & -0.59 & ns \\
$\mathrm{Mg}, \mathrm{cmol}_{\mathrm{c}} \mathrm{dm}^{-3}$ & 0.70 & 0.65 & 42.98 & 0.10 & 1.40 & 0.3 & -0.74 & ns \\
$\mathrm{SB}, \mathrm{cmol}_{\mathrm{c}} \mathrm{dm}^{-3}$ & 5.39 & 5.30 & 14.77 & 3.70 & 7.30 & 0.18 & -0.63 & ns \\
$\mathrm{H}+\mathrm{Al}_{\mathrm{cmol}} \mathrm{dm}^{-3}$ & 1.61 & 1.65 & 29.47 & 0.66 & 2.81 & 0.56 & 0.03 & ns \\
$\mathrm{P}, \mathrm{mg} \mathrm{dm}^{-3}$ & 49.00 & 43.17 & 43.63 & 13.12 & 98.19 & 0.63 & -0.54 & $*$ \\
$\mathrm{CEC}, \mathrm{cmol}_{\mathrm{c}} \mathrm{dm}^{-3}$ & 7.08 & 6.95 & 15.46 & 4.86 & 9.74 & 0.52 & -0.05 & ns \\
$\mathrm{V}, \%$ & 77.32 & 76.92 & 6.77 & 64.03 & 87.16 & -0.13 & -0.66 & ns \\
$\mathrm{OM}, \mathrm{g} \mathrm{kg}^{-1}$ & 9.18 & 9.31 & 18.47 & 6.18 & 13.47 & 0.02 & -0.36 & ns \\
$\mathrm{N}, \mathrm{g} \mathrm{kg}^{-1}$ & 0.82 & 0.81 & 10.69 & 0.67 & 1.02 & 0.17 & -0.76 & ns \\
\hline
\end{tabular}

CV: coefficient of variation; K-S: Kolmogorov-Smirnov test $(\mathrm{P}=0.05)(*)$ significant and $\left({ }^{\mathrm{ns}}\right)$ : no significant.

$\mathrm{pH}$, saturation by bases and the $\mathrm{Na}$ and $\mathrm{N}$ contents presented low variability, following the CV classification by Warrick and Nielsen (1980). The other attributes presented mean variability, where the highest value of the $\mathrm{CV}$ of the $\mathrm{P}$ outstands. This variability observed in the attributes has been reported by different authors (Silva and Chaves, 2001; Yemefack et al., 2005; Camacho-Tamayo et al., 2008), who also emphasized the behavior of $\mathrm{P}$, element that is distributed superficially or incorporated in the first centimeters of soil.

It was observed that the attributes formed two groups in the factor analysis by principal components. The first group is formed by $\mathrm{pH}, \mathrm{H}+\mathrm{Al}$, $\mathrm{MO}, \mathrm{P}$ and $\mathrm{Mg}$. The second group is formed by $\mathrm{N}, \mathrm{Na}, \mathrm{K}, \mathrm{SB}$ and CEC (Figure 1). It is evident that the $\mathrm{Na}$ and $\mathrm{K}$ contents presented a higher influence on the SB and CEC behavior, compared to the other cations (Figure 1). The attributes $\mathrm{Ca}$ and $\mathrm{V}$ were presented isolated; the exchangeable acidity presented an inverse relation with the bases saturation, and the $\mathrm{pH}$ did with the sum of bases.

The first four components were considered in the factors analysis, with eigenvalues higher than one, which in this case, showed an acceptable interval (Kaiser and Rice, 1974). These principal components explain approximately $75 \%$ of the total variance (Table 2 ). It was observed that the lowest communality values were
$\mathrm{P}, \mathrm{MO}$ and $\mathrm{N}$, indicating that these attributes are slightly representative in the principal components analyzed. PC1 represented $32.43 \%$ of the total variance influenced by the attributes $\mathrm{Na}, \mathrm{K}, \mathrm{SB}$ and $\mathrm{CEC}$, showing a strong relation among these attributes, in addition to an inverse correlation with $\mathrm{pH}$. PC2 represented $21.58 \%$ of the total variance, evidencing an increasing influence of $\mathrm{H}+\mathrm{Al}$ and $\mathrm{SB}$, attributes that are inversely correlated, as observed in Figure 1. PC3 represented $11.29 \%$ of the total variance, showing the correlation existing between $\mathrm{pH}$ and $\mathrm{Mg}$, possibly due to the superficial distribution of dolomite lime $(30.4 \%$ of $\mathrm{CaO}$ and $21.95 \%$ of $\mathrm{MgO}$ ). PC4 presented $9.50 \%$ of the total variance, revealing $\mathrm{Ca}$ as the attribute better explaining the behavior of this component.

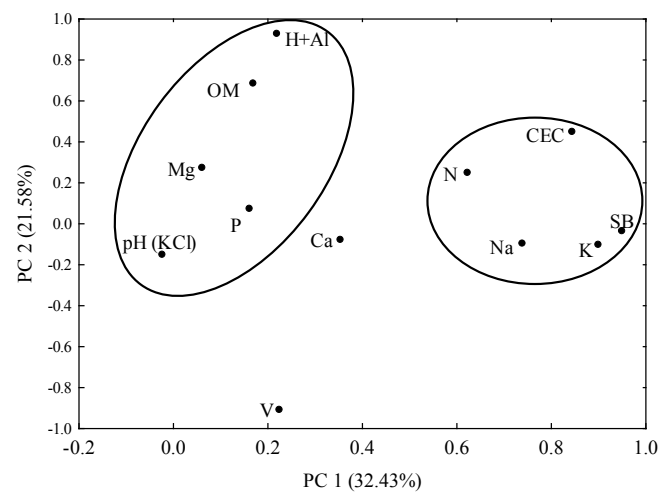

Figure 1. Factor analysis of principal components of chemical attributes with Varimax rotation for the first two components. 
Table 2. Coefficients of the first four components of the attributes $\mathrm{pH}, \mathrm{Ca}, \mathrm{Na}, \mathrm{K}, \mathrm{Mg}$, sum of bases (SB), exchangeable acidity $(\mathrm{H}+\mathrm{Al}), \mathrm{P}$, cation exchange capacity $(\mathrm{CEC})$, base saturation $(\mathrm{V})$, organic matter $(\mathrm{OM})$ and $\mathrm{N}$.

\begin{tabular}{lccccc}
\hline Attribute & PC1 & PC2 & PC3 & PC4 & Communality \\
\hline $\mathrm{pH}(\mathrm{KCl})$ & -0.022 & -0.154 & 0.821 & 0.240 & 0.756 \\
$\mathrm{Ca}$ & 0.354 & -0.080 & 0.035 & 0.842 & 0.842 \\
$\mathrm{Na}$ & 0.738 & -0.100 & -0.061 & -0.137 & 0.577 \\
$\mathrm{~K}$ & 0.901 & -0.103 & -0.195 & 0.001 & 0.861 \\
$\mathrm{Mg}$ & 0.062 & 0.271 & 0.703 & -0.538 & 0.862 \\
$\mathrm{SB}$ & 0.950 & -0.034 & 0.109 & 0.210 & 0.960 \\
$\mathrm{H}+\mathrm{Al}$ & 0.219 & 0.926 & 0.012 & -0.045 & 0.908 \\
$\mathrm{P}$ & 0.161 & 0.075 & -0.268 & -0.483 & 0.336 \\
$\mathrm{CEC}$ & 0.845 & 0.449 & 0.090 & 0.138 & 0.942 \\
$\mathrm{~V}$ & 0.225 & -0.911 & 0.040 & 0.112 & 0.894 \\
OM & 0.169 & 0.686 & 0.077 & -0.030 & 0.506 \\
$\mathrm{~N}$ & 0.623 & 0.248 & 0.133 & 0.254 & 0.532 \\
Eigenvalue & 3.891 & 2.590 & 1.355 & 1.140 & 9.50 \\
Total Variance, \% & 32.43 & 21.58 & 11.29 & 65.30 & \\
Cumulative variance, \% & 32.43 & 54.01 & 65.30 & & \\
\hline
\end{tabular}

Loading factors higher than 0.7 (absolute value) are shown in italic.

The analysis of hyerarchical cluster identified two groups, similar to the groups found in the factor analysis. The first group is related to the presence of cations, formed by CEC, SB, K, Na, $\mathrm{V}, \mathrm{N}$ and $\mathrm{Ca}$. The second group is composed mainly by attributes helping the description of soil acidity, formed by $\mathrm{P}, \mathrm{MO}, \mathrm{H}+\mathrm{Al}, \mathrm{Mg}$ and $\mathrm{pH}$. The strong influence that $\mathrm{K}$ in $\mathrm{SB}$ presented in this soil was also verified, as well as in CEC, along with $\mathrm{Na}$, where these attributes formed a subgroup. Likewise, the influence of $\mathrm{Mg}$ on the $\mathrm{pH}$ behavior was confirmed.

The results of the theoretical model fit of isotropic semivariograms showed that the predominant model was spherical, followed by the exponential and Gaussian models (Table 3). The $\mathrm{pH}$ was the only attribute that presented an undefined spatial dependence, as the distribution of this attribute in soil is randomized, presenting a pure nugget effect (EPP). The determination coefficient $\left(\mathrm{R}^{2}\right)$ was always higher than 0.80 for the attributes presenting spatial dependence, where $\mathrm{Mg}, \mathrm{H}+\mathrm{Al}, \mathrm{P}, \mathrm{MO}$ and $\mathrm{N}$ were the attributes showing the best fit. These $\mathrm{R}^{2}$ values, along the cross validation for all the attributes, indicate adequate data reliability. Studies developed by different authors obtained theoretical semivariograms models fitting for chemical attributes (Silva and Chaves, 2001; Gallardo and Paramá, 2007 and Camacho-Tamayo et al., 2008).
The attributes $\mathrm{K}, \mathrm{H}+\mathrm{Al}$ and $\mathrm{MO}$ presented the highest ranges, with distances higher than $80 \mathrm{~m}$ and a mean dependence degree. Lower ranges were found for $\mathrm{SB}, \mathrm{Ca}$ and $\mathrm{Na}$. Most of the attributes presented a moderate GDE, except SB, $\mathrm{P}$ and $\mathrm{V}$, which presented a strong GDE; these attributes were fitted to theoretical exponential models.

Phosphorous was the only attribute presenting non significant correlations with the other attributes (Table 4), showing an inverse correlation of this attribute with $\mathrm{pH}$, which indicates that the higher $\mathrm{pH}$, the lower the $\mathrm{P}$ presence. However, it is observed a positive correlation between phosphorous and MO. A contrary situation was observed for CEC that presented the largest cluster of significant correlations with the other attributes, especially with $\mathrm{SB}$. The $\mathrm{pH}$ presented a significant and positive correlation with $\mathrm{Mg}$ and $\mathrm{Ca}$, which was stronger with $\mathrm{Mg}$, as also observed in the hierarchical cluster. An inverse correlation was observed between $\mathrm{pH}$ and $\mathrm{K}, \mathrm{P}$, exchangeable acidity and MO.

The strong influence of $\mathrm{K}$ on $\mathrm{SB}$ and $\mathrm{CEC}$ is also confirmed by the high positive correlation among these attributes, which was verified by the factor analysis (Figure 1) and the hierarchi- 
Table 3. Parameters of semivariogram models for $\mathrm{pH}, \mathrm{Ca}, \mathrm{Na}, \mathrm{K}, \mathrm{Mg}$, sum of bases (SB), exchangeable acidity $(\mathrm{H}+\mathrm{Al})$, $\mathrm{P}$, cation exchange capacity (CEC), base saturation (V), organic matter (OM) and $\mathrm{N}$.

\begin{tabular}{lccccccc}
\hline Attribute & Model & Co & Co $+\mathrm{C}$ & Range, $\mathrm{m}$ & $\mathrm{C} / \mathrm{Co}+\mathrm{C}$ & $\mathrm{R}^{2}$ & \multicolumn{2}{c}{$\mathrm{VC}$} \\
\hline $\mathrm{pH}(\mathrm{KCl})$ & $\mathrm{PPE}$ & 0.094 & 0.094 & $\mathrm{ND}$ & 0 & 0 & 0.430 \\
$\mathrm{Ca}$ & Spherical & 0.027 & 0.074 & 39.10 & 0.637 & 0.83 & 0.93 \\
$\mathrm{Na}$ & Spherical & 0.004 & 0.014 & 43.30 & 0.741 & 0.84 & 0.90 \\
$\mathrm{~K}$ & Spherical & 0.200 & 0.402 & 92.40 & 0.502 & 0.94 & 1.05 \\
$\mathrm{Mg}$ & Spherical & 0.030 & 0.103 & 64.70 & 0.708 & 0.99 & 0.99 \\
$\mathrm{SB}$ & Exponential & 0.096 & 0.688 & 42.60 & 0.860 & 0.87 & 0.96 \\
$\mathrm{H}+\mathrm{Al}$ & Gaussian & 0.108 & 0.312 & 86.60 & 0.654 & 0.99 & 1.00 \\
$\mathrm{P}$ & Exponential & 43.500 & 283.00 & 56.10 & 0.846 & 0.99 & 0.91 \\
$\mathrm{CEC}$ & Spherical & 0.466 & 0.963 & 72.00 & 0.516 & 0.95 & 1.00 \\
$\mathrm{~V}$ & Exponential & 5.710 & 31.040 & 79.50 & 0.974 & 0.82 & 0.94 \\
$\mathrm{OM}$ & Gaussian & 0.870 & 2.968 & 82.97 & 0.707 & 0.98 & 1.05 \\
$\mathrm{~N}$ & Spherical & 0.003 & 0.006 & 63.9 & 0.556 & 0.96 & 0.99 \\
\hline
\end{tabular}

PPE: pure nugget effect; VC: cross validation coefficient; ND: Not defined.

Table 4. Pearson correlation of the attributes $\mathrm{pH}, \mathrm{Ca}, \mathrm{Na}, \mathrm{K}, \mathrm{Mg}$, sum of bases (SB), exchangeable acidity $(\mathrm{H}+\mathrm{Al}), \mathrm{P}$, cation exchange capacity (CEC), base saturation (V), organic matter (OM) and N.

\begin{tabular}{|c|c|c|c|c|c|c|c|c|c|c|c|}
\hline & $\mathrm{pH}$ & $\mathrm{Ca}$ & $\mathrm{Na}$ & K & $\mathrm{Mg}$ & SB & $\mathrm{H}+\mathrm{Al}$ & $\mathrm{P}$ & CEC & $\mathrm{V}$ & $\mathrm{OM}$ \\
\hline $\mathrm{Ca}$ & $0.216^{*}$ & 1 & & & & & & & & & \\
\hline $\mathrm{Na}$ & -0.030 & 0.086 & 1 & & & & & & & & \\
\hline K & -0.120 & $0.235^{*}$ & $0.584 * *$ & 1 & & & & & & & \\
\hline $\mathrm{Mg}$ & $0.237^{*}$ & $-0.366 * *$ & -0.047 & -0.145 & 1 & & & & & & \\
\hline SB & 0.096 & $0.547 * *$ & $0.586^{* *}$ & $0.872 * *$ & 0.053 & 1 & & & & & \\
\hline $\mathrm{H}+\mathrm{Al}$ & -0.094 & -0.073 & 0.110 & 0.153 & $0.263 * *$ & 0.181 & 1 & & & & \\
\hline $\mathrm{P}$ & -0.166 & -0.135 & -0.005 & 0.094 & 0.054 & 0.020 & 0.052 & 1 & & & \\
\hline CEC & 0.026 & $0.384 * *$ & $0.508 * *$ & $0.751 * *$ & 0.175 & $0.863 * *$ & $0.652 * *$ & 0.042 & 1 & & \\
\hline V & 0.106 & $0.293 * *$ & 0.167 & $0.250^{*}$ & $-0.203^{*}$ & $0.279 * *$ & $-0.879 * *$ & -0.06 & $-0.236^{*}$ & 1 & \\
\hline $\mathrm{OM}$ & -0.109 & 0.043 & 0.069 & -0.021 & $0.281 * *$ & 0.111 & $0.495 * *$ & 0.170 & $0.340 * *$ & $-0.399 * *$ & 1 \\
\hline $\mathrm{N}$ & 0.039 & $0.407 * *$ & $0.339 * *$ & $0.405 * *$ & 0.092 & $0.571 * *$ & $0.232 *$ & 0.077 & $0.559 * *$ & 0.02 & $0.384 * *$ \\
\hline
\end{tabular}

$* \mathrm{P} \leq 0.05 ; * * \mathrm{P} \leq 0.01$.

cal cluster analysis (Figure 2). This influence is also observed in the contour maps (Figures 3 and 4), where areas with high $\mathrm{K}$ content correspond to zones with higher CEC and SB values. In the same way, the similarity observed between MO and the exchangeable acidity in the hierarchical cluster analysis is confirmed by the positive correlation among these attributes, in addition to the similarity among the contour maps obtained by kriging. The influence of $\mathrm{Ca}$ on $\mathrm{SB}$ is also verified, where $\mathrm{Mg}$ is the cation with lower influence on SB and CEC. 


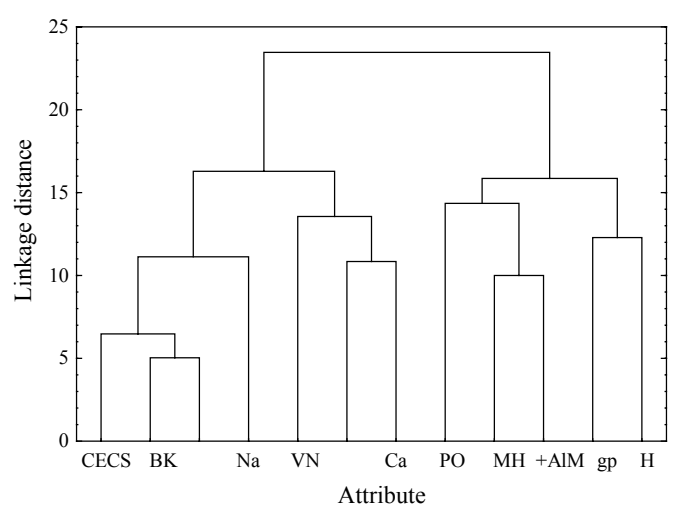

Figure 2. Dendrogram resulting from cluster analysis, showing the formation of attributes groups for $\mathrm{pH}, \mathrm{Ca}, \mathrm{Na}$, $\mathrm{K}, \mathrm{Mg}$, sum of bases (SB), exchangeable acidity $(\mathrm{H}+\mathrm{Al})$, $\mathrm{P}$, cation exchange capacity (CEC), bases saturation (V), organic matter $(\mathrm{OM})$ and $\mathrm{N}$.

The resulting contour maps confirmed the relation among the different attributes (Figures 3 and 4), as well as the variability existing in the soil, which indicates that a future application using variable rate techniques of different fertilizers and amendments, based on the requirements of the crop, is a convenient way to improve their use, as well as to diminish production costs and environmental impact, due to the excesses or deficiencies on the input distribution when conventionally distributed on the soil with a uniform rate.

The different attributes presented low or mean variability, where $\mathrm{pH}$ was the only attribute that did not show spatial dependence. The other attributes studied presented spatial dependence, identifying different zones using the elaboration of contour maps, which are basic for the specific management of agricultural input distributions, especially fertilizers.
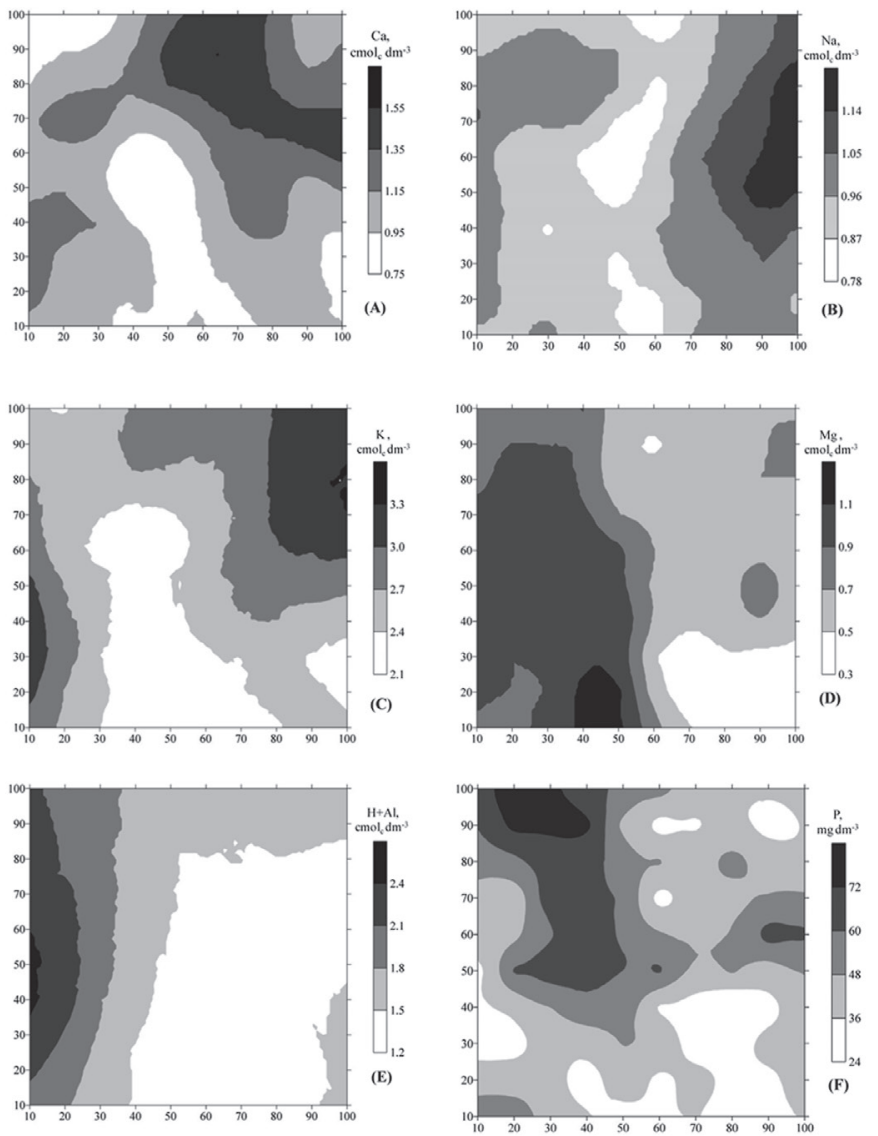

Figure 3. Contour maps obtained by kriging for $\mathrm{Ca}(\mathrm{A}), \mathrm{Na}(\mathrm{B}), \mathrm{K}(\mathrm{C}), \mathrm{Mg}$ (D), $\mathrm{H}+\mathrm{Al}(\mathrm{E})$ and $\mathrm{P}(\mathrm{F})$. 
The use of different statistical tools helped identify the spatial soil variability, as well as in the comprehension and determination of the different relations among attributes characterizing the soil, techniques that may help in decision making for a better organization and control of agricultural production.
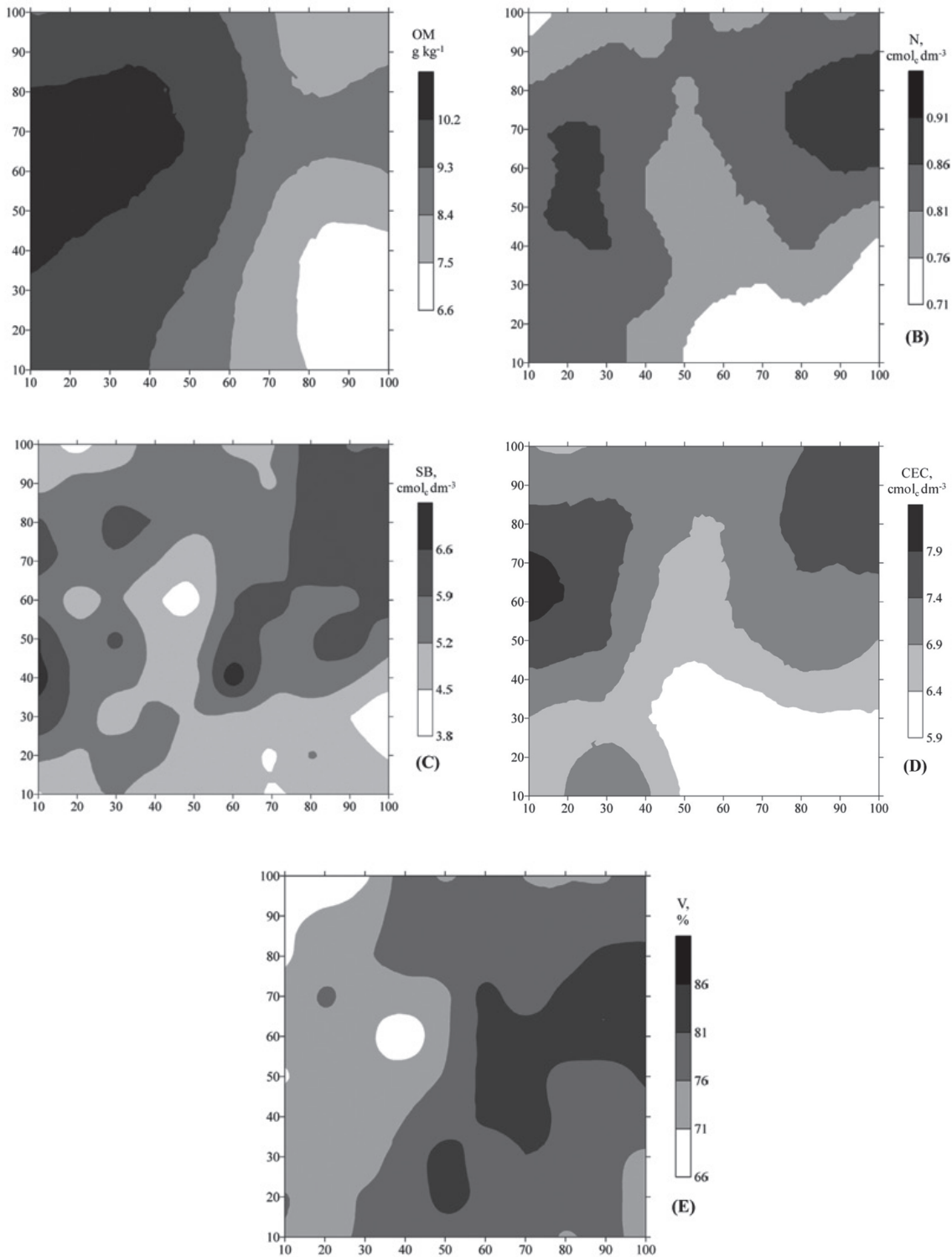

Figure 4. Contour maps obtained by kriging for OM (A), N (B), SB (C), CEC (D) y V (E). 


\title{
Resumen
}

\begin{abstract}
J. Silva Cruz, R. N. de Assis Júnior, S. S. Rocha Matias y J. Camacho-Tamayo. 2011. Variabilidad espacial de un Alfisol cultivado con caña de azúcar. Cien. Inv. Agr. 38(1): 155-164. La variabilidad del suelo ocurre debido a factores que actúan en varias escalas espaciales y temporales, naturales o antrópicas. El objetivo del presente estudio fue evaluar la variabilidad espacial y la relación de algunos atributos químicos, mediante diferentes técnicas estadísticas. El trabajo fue realizado en el municipio de Maracanaú (CE, Brasil), en área comercial de caña de azúcar, en un Typic Hapludalfs. Se tomaron muestras de suelo cada $10 \mathrm{~m}$, en una malla regular de $100 \mathrm{~m}$ x $100 \mathrm{~m}$, en una capa entre 0 y $0,20 \mathrm{~m}$, para la determinación de acidez intercambiable, $\mathrm{pH}(\mathrm{KCl}), \mathrm{Ca}, \mathrm{Na}, \mathrm{K}, \mathrm{Mg}, \mathrm{P}, \mathrm{N}$, suma de bases, capacidad de intercambio catiónica, saturación de bases y materia orgánica. Los datos fueron analizados mediante estadística descriptiva, multivariada y, geoestadística e interpolación por kriging ordinario. Los atributos presentaron variabilidad baja o media, donde el $\mathrm{pH}$ fue el único atributo que no presentó dependencia espacial. Las diferentes técnicas estadísticas ayudaron a caracterizar la variabilidad espacial del suelo y la identificación de las diferentes relaciones entre atributos, cuyos resultados permiten una mejor planeación y control en la producción agrícola, especialmente en la realización de prácticas de manejo localizado de insumos agrícolas.
\end{abstract}

Palabras clave: Geoestadística, componentes principales, agrupamiento jerárquico.

\section{References}

Berner, P.G.M., S.R. Vieira, E. Lima, and L.H.C. Anjos. 2007. Variabilidade espacial de propriedades físicas e químicas de um Cambissolo sob dois sistemas de manejo de cana-de-açúcar. Revista Brasileira de Ciência do Solo 31:837-844.

Bouma, J., B.J. Van Alphen Stoorvogel, and H.W.G. Booltink. 1999. Pedology, precision agriculture, and the changing paradigm of agricultural research. Soil Science of Society American Journal 63:1763-1768.

Burgos, P., E. Madejón, A. Pérez-de-Mora, and F. Cabrera. 2006. Spatial variability of the chemical characteristics of a trace-element-contaminated soil before and after remediation. Geoderma 130:157-175.

Burrough, P. A. 1993. Soil variability: a late 20th century view. Soils and Fertilizers 56:529-562.

Camacho-Tamayo, J.H, C.A. Luengas, and F.R. Leiva. 2008. Effect of agricultural intervention on the spatial variability of some soils chemical properties in the eastern plains of Colombia. Chilean Journal of Agricultural Research 68:42-55.

Cambardella, C.A., T.B. Moorman, J.M. Novak, T.B. Parkin, D.L. Karlen, R.F. Turco, and A.E. Konopka. 1994. Field-scale variability of soil properties in Central Iowa Soils. Soil Science Society American Journal 58:1501-1511.
Corá, J.E., A.V. Araujo, G.T. Pereira, and J.M.G. Beraldo. 2004. Variabilidade espacial de atributos do solo para adoção do sistema de agricultura de precisão na cultura de cana-de-açúcar. Revista Brasileira de Ciência do Solo 28:1013-1021 .

Cressie, N. 1993. Statistics for spatial data. Revised Edition. John Wiley \& Sons, New York, USA. $928 \mathrm{pp}$.

Diggle, P.J., and J.R. Ribeiro. 2000. Model Based Geostatistics. 1. ed. São Paulo: Associação Brasileira de Estatística. 129 pp.

Fidalski, J., C.A. Tormena, and C.A. Scapim. 2007. Espacialização vertical e horizontal dos indicadores de qualidade para um Latossolo Vermelho cultivado com citros. Revista Brasileira de Ciência do Solo 31:9-19.

Gallardo, A., and R. Paramá. 2007. Spatial variability of soil elements in two plant communities of NW Spain. Geoderma 139:199-208.

Godwin, R.J., and P.C.H. Miller. 2003. A review of the technologies for mapping within-field variability. Biosystems Engeneering 84:393-407.

Golden Software. 1999. Surface mapping system Inc. Surfer. Surfer version 7.00. Golden Software, Inc. Colorado. 619 pp.

Goovaerts, P. 1998. Geostatistical tools for characterizing the spatial variability of microbiological and physico-chemical soil properties. Biology and Fertility of Soils 27:315-34. 
Kaiser, H.F., and J. Rice. 1974. Little jiffy, mark IV. Educational and Psychological Measurement 34:111-117.

Köppen, W. 1936. Das geographisca System der Klimate, in: Handbuch der Klimatologie. Köppen, W. and Geiger, G. (eds.), 1. C.Gebr, Borntraeger. p. 1-44.

Manly, B.F.J. 1997. Multivariate statistical methods. A primer. Second Ed. Chapman \& Hall, London. $216 \mathrm{pp}$.

Mello, G., C.R.P. Bueno, and G.T. Pereira, G. T. 2006. Variabilidade espacial das propriedades físicas e químicas do solo em áreas intensamente cultivadas. Revista Brasileira de Engenharia Agrícola e Ambiental 10:294-305.

Ramos, M.C., R. Cots-Folch, and J.A. Martínez-Casasnovas. 2007. Effects of land terracing on soil properties in the Priorat region in Northeastern Spain: A multivariate analysis. Geoderma 142:51-261.

Rezaei, S.A., and R.J. Gilkes. 2005. The effects of landscape attributes and plant community on soil physical properties in rangelands. Geoderma 125:145-154.

Robertson, G.P. 1998. GS+: Geostatistics for the environmental sciences - GS+ users guide. Plainwell: Gamma Desing Software. 152 pp.

Silva, P.C.M. da, and L.H.G. Chaves. 2001. Avaliação e variabilidade espacial de fósforo, potás- sio e matéria orgânica em Alissolos. Revista Brasileira de Engenharia Agrícola e Ambiental 5:431-436.

Theodoro, V.C.A., M.I.N. Alvarenga, R.J. Guimaraes, and C.A.S. Souza. 2003. Alterações químicas em solo submetido a diferentes formas de manejo do cafeeiro. Revista Brasileira de Ciência do Solo 27:1039-1047.

Vieira, S.R. 2000. Geoestatística em estudos de variabilidade espacial do solo. In: P.F. Novais, V.H. Alvarez and C.E.G.R. Schaefer (eds.). Tópicos em ciência do solo. Viçosa: Sociedade Brasileira de Ciência do Solo. 1:1-54.

Warrick, A.W., and D.R. Nielsen. 1980. Spatial variability of soil physical properties in the field. In: D. Hillel (ed.) Applications of soil physics. New York: Academic Press. p. 319344.

Webster, R. 2008. Soil science and geostatistics. In: P. Krasilnikov, F. Carré and L. Montanarella (eds.). Soil geography and geostatistics - concepts and applications. European Commission, Joint Research Centre, Institute for Environment and Sustainability. p. 1-11.

Yemefack, M., D.G. Rossiter, and R. Njomgang. 2005. Multi-scale characterization of soil variability within an agricultural landscape mosaic system in southern Cameroon. Geoderma 125:117-143. 